\title{
PENGARUH DIVIDEN ANNOUNCEMENT, CAPITAL GAIN DAN KURS TERHADAP TRADING VOLUME ACTIVITY (Studi Kasus pada Saham Syariah yang Terdaftar di JII Tahun 2015-2018)
}

\author{
Bella Atika \\ Fakultas Ekonomi dan Bisnis Islam UIN Sunan Kalijaga Yogyakarta \\ Email: bellaatika.23@gmail.com
}

\begin{abstract}
The capital market is a company tool to increase long-term funding needs by selling shares and issuing bonds. A measurement tool for calculating trading volume is trading volume activity (TVA). The purpose of this study is to examine the effect of dividend announcements, capital gains and exchange rates on trading volume activity (TVA) on Islamic stocks listed on JII in 2015 to 2018. This study uses eight Islamic shares, namely ADRO, ASII, INDF, LPFF, PGAS, PTBA, $S M R A$ and UNTR. The data in this study were obtained through an annual report from the IDX website. Based on paired differences test shows that in 2105, 2016 and 2017 there were no significant TVA differences between before and after dividend announcements, whereas in 2018 there were significant TVA differences between before and after dividend announcements. The panel data regression analysis results showed that the capital gain variable has no effect on TVA, while the exchange rate variable has a positive and significant effect on TVA.

Keywords: Trading Volume Activity, Dividen Announcements, Capital Gain, Kurs
\end{abstract}

\begin{abstract}
ABSTRAK
Pasar modal merupakan sarana perusahaan untuk meningkatkan kebutuhan dana jangka panjang dengan menjual saham dan mengeluarkan obligasi. Alat ukur untuk menghitung volume perdagangan yaitu trading volume activity (TVA). Tujuan dari penelitian ini adalah untuk menguji pengaruh dividen announcements, capital gain dan kurs terhadap trading volume activity (TVA) pada saham syariah yang terdaftar di JII tahun 2015 hingga 2018. Penelitian ini menggunakan delapan saham syariah, yaitu ADRO, ASII, INDF, LPFF, PGAS, PTBA, SMRA dan UNTR. Data dalam penelitian ini diperoleh melalui annual report dari website idx. Berdasarkan uji beda berpasangan menunjukkan bahwa tahun 2105, 2016 dan 2017 tidak terdapat perbedaan TVA yang signifikan antara sebelum dan sesudah pengumuman dividen, sedangkan tahun 2018 terdapat perbedaan TVA yang signifikan antara sebelum dan sesudah pengumuman dividen. Hasil analisis regresi data panel diperoleh hasil bahwa variabel capital gain tidak berpengaruh terhadap TVA, sedangkan variabel kurs berpengaruh positif dan signifikan terhadap TVA
\end{abstract}

Kata kunci: Trading Volume Activity, Dividen Announcements, Capital Gain, Kurs

\section{PENDAHULUAN}

Perkembangan pasar modal saat ini sudah sangat luas dimana dapat dilihat dengan munculnya berbagai macam instrumen, seperti saham, obligasi dan 
derivatif. Pasar modal merupakan sarana perusahaan dalam rangka meningkatkan kebutuhan dana jangka panjang dengan menjual saham dan mengeluarkan obligasi. Menurut Jogiyanto (2008) di pasar modal terdapat lebih dari setahun masa pengembalian pinjaman.

Di dalam pasar modal banyak dijumpai kegiatan berinvestasi. Investor dalam berinvestasi tentu tidak secara asal, melainkan memiliki perhitungan tersendiri. Peneliti berasumsi bahwa seorang calon investor akan membuat keputusan untuk berinvestasi atau tidak didasarkan pada beberapa hal, seperti pengumuman dividen, capital gain dan kurs untuk melihat apakah calon investor akan terpengaruh oleh ketiga variabel tersebut dalam berinvestasi.

Menurut Kim, et.al (2017) investor individu adalah kelompok investor yang paling responsif terhadap laporan analis pada perusahaan kecil. Sedangkan untuk investor institusi lebih responsif terhadap laporan perusahaan dengan mengabaikan volatiltas return yang tinggi.

Perkembangan tersebut juga berlaku bagi pasar modal syariah yang mana tidak jauh berbeda dengan pasar modal konvensional, namun terdapat beberapa karakteristik khusus. Dimana karakteristik tersebut tidak bertentangan dengan prinsip-prinsip syariah yakni, dengan menjauhi riba, gharar, maisir baik dari segi produk dan mekanisme transaksi.

Pasar modal dikatakan efisien jika harga saham yang ada merefleksikan semua informasi. Informasi ini selanjutnya dapat menimbulkan suatu reaksi pasar yang mana selanjutnya dapat untuk mengetahui trading volume. Trading volume sendiri merupakan gambaran kondisi efek di pasar modal yang diperjualbelikan. Alat ukur yang dapat digunakan untuk mengukur volume perdagangan, yaitu trading volume activity (TVA). Semakin tinggi nilai TVA, maka dapat diketahui bahwa saham tersebut semakin likuid, begitu juga sebaliknnya.

Salah satu informasi yang dapat mempengaruhi reaksi pasar, yakni dividen announcements. Dimana pembayaran dividen oleh perusahaan dapat menjadi penyampaian informasi yang terpercaya dan sulit untuk ditiru oleh perusahaan dengan kinerja yang buruk. Setiap kebijakan dividen dapat menjadi bahan penilaian oleh investor selaku pihak yang tidak mengetahui informasi detail terkait perusahaan. Beberapa penelitian yang mendukung bahwa dividen merupakan penyampaian infomasi, seperti Lintner (1956), Fama dan Babiak (1968) dimana seorang manajer dalam menetapkan besaran dividen menerapkan prinsip kehati-hatian, karena dianggap sebagai beban. Ketika laba perusahaan meningkat, manajer tidak secara langsung menaikkan dividen, melainkan menunggu beberapa waktu hingga yakin bahwa tingkat laba saat ini akan mampu dipertahankan di masa yang akan datang.

Selanjutnya, saham dikatakan likuid apabila saham tersebut sangat mudah untuk dijual atau karena banyak investor yang bersedia untuk membeli. Salah satu faktor yang menentukan keputusan investor untuk menjual atau membeli saham adalah harga saham. Ketika harga saham naik, maka investor akan menjual sahamnya begitu juga sebaliknya ketika harga saham turun, maka investor akan membeli saham.

Harga saham dapat menjadi cerminan nilai perusahaan dimana ketika harga saham tinggi, maka hal tersebut dapat diartikan kinerja perusahaan dalam kondisi baik, begitu pula sebaliknya. Namun, saham dengan harga yang terlalu tinggi dapat menjadi pertimbangan bahkan mengurangi keinginan investor untuk membeli, sehingga perusahaan melakukan stock split. Stock split adalah 
pemecahansatu lembar saham menjadi sejumlah lembar saham. Kegiatan tersebut tidak menambah nilai perusahaan, melainkan hanya menambah jumlah lembar saham. Stock split dilakukan supaya saham dengan harga yang dianggap terlalu tinggi dapat dibeli oleh investor dengan harga yang lebih rendah.

Kemudian, perusahaan dalam melakukan kegiatan operasionalnya tidak menutup kemungkinan melakukan ekspor maupun impor. Baik dalam rangka mendatangkan bahan baku atau pendistribusian barang produksi. Maka dari itu nilai tukar mata uang juga memberikan peran bagi kegiatan investasi mereka. Nilai tukar suatu negara juga akan mempengaruhi keputusan investor asing dalam mengambil keputusan dalam rangka investasi.

Kegiatan menjual dan membeli saham akan mendatangkan capital gain atau capital loss. Dimana capital gain merupakan keuntungan kelebihan dari selisih harga jual dengan harga beli saham. Sedangkan capital loss merupakan kerugian dari selisih harga jual saham dan harga beli saham. Dimana keuntungan yang diperoleh akan berdampak pada peningkatan penjualan saham. Maka dari itu terdapat dua keuntungan yang akan diperoleh pemegang saham, yakni dividen dan capital gain.

Objek penelitian ini, yaitu saham syariah yang terdaftar di Jakarta Islamic Index (JII) pada tahun 2015 hingga 2018. Alasan peneliti memilih JII karena merupakan indeks saham syariah yang selalu meng-update data terkait 30 perusahaan yang sesuai dengan kriteria syariah.

Berdasarkan penelitian-penelitian terdahulu masih terdapat pro kontra hasil penelitian.

Menurut Subiyanto (2015) pengumuman pembagian dividen tidak signifikan terhadap volume perdagangan saham. Sejalan dengan hal itu Mudalige dan Kalev (2016) menunjukkan bahwa investor institusi menunjukkan abnormal trading volume sebelum pengumuman dan sesudah dividen diumumkan. Namun, investor individu menunjukkan abnormal trading volume hanya setelah pengumuman dividen. Konsisten dengan hasil yang diharapkan dimana abnormal trading volume secara statistik tidak signifikan di sekitar pengumuman dividen.

Sedangkan menurut Kayan dkk. (2018) terdapat perbedaan hasil, dimana pada tahun 2016 tidak terdapat adanya perbedaan signifikan antara trading volume activity sebelum dan sesudah dividen diumumkan, sementara pada tahun 2017 terdapat perbedaan yang signifikan. Selanjutnya, menurut Sudibyo (2016) dividen memiliki pengaruh positif dan signifikan terhadap volume perdagangan saham.

Menurut Prasetioningsih, dkk (2016) nilai tukar rupiah berpengaruh positif dan signifikan terhadap return saham. Sedangkan menurut Rahmi dan Jamal (2019) kurs rupiah tidak berpengaruh terhadap volume perdagangan saham.

Menurut Subiyanto (2015) capital gain berpengaruh terhadap volume perdagangan saham. Sejalan dengan hasil penelitian tersebut Sudibyo (2016) menunjukkan bahwa capital gain berpengaruh positif dan signifikan terhadap volume perdagangan saham. Menurut Kumar (2019) hubungan antara trading volume dan volatilitas nilai tukar adalah signifikan dan negatif.

Perbedaan penelitian ini dengan penelitian terdahulu yaitu menggunakan dividen announcements, capital gaindan kurs sebagai variabel independendan trading volume activity sebagai variabel dependen. Dimana dalam penelitian terdahulu dalam menguji trading volume hanya menggunakan variabel dividen dan capital gain atau hanya kurs saja. Disini penulis mencoba menggabungkan ketiga variabel independen untuk melihat pengaruhnya terhadap variabel 
dependen. Serta objek penelitian yang digunakan yakni saham syariah yang terdaftar di JII pada tahun 2015-2018. Melihat objek penelitian terdahulu terkait trading volume rata-rata memilih perusahaan manufaktur, asuransi, keuangan yang terdaftar di BEI. Berdasarkan uraian di atas, maka penulis tertarik untuk meneliti lebih lanjut mengenai trading volume activity di perusahaan-perusahaan syariah yang terdaftar di JII.

\section{TINJAUAN PUSTAKA DAN PENGEMBANGAN HIPOTESIS Teori Signaling}

Teori ini digagas oleh Ackerlof, Spece dan Stiglitz yang dikembangkan dalam ilmu ekonomi dan keuangan bahwasannya pihak dari dalam perusahaan pada umumnya memiliki informasi yang lebih akurat dibandingkan dengan pihak luar (investor). Sampai pada akhirnya muncul asymmetric information yang membuat investor kesulitan dalam menilai kualitas perusahaan. Munculnya masalah tersebut membuat investor untuk memberi penilaian yang lebih rendah terhadap semua saham perusahaan baik yang berkualitas baik ataupun buruk

Perusahaan yang berkualitas baik tentu ingin memberi keyakinan pada investor terkait kinerjanya. Perusahaan dalam menyampaikan informasi terkait kualitas perusahaan dengan cara yang tidak dapat ditiru oleh perusahaan lainnyaatau dengan kualitas buruk. Salah satu caranya adalah dengan memberikan signal yang membutuhkan biaya yang relatif mahal, yakni dengan membayarkan dividen dengan jumlah yang relatif besar. Model signaling ini juga konsisten dengan observasi bahwa pasar akan merespon dengan harga yang meningkat dengan adanya peningkatan dividen, serta menurun dalam jumlah besar ketika terjadi pemotongan dividen (Arifin, 2007).

\section{Trading Volume Activity}

Trading volume activity merupakan suatu pengukuran apakah pengumuman dari perusahaan akan berpengaruh terhadap kenaikan TVA perusahaan yang bersangkutan (Kristiyanto dan Hermuningsih, 2018). Volume perdagangan saham merupakan indikator yang digunakan untuk menilai harga saham, serta melihat reaksi pasar modal terhadap informasi melalui pergerakan aktivitas volume perdagangan saham. Oleh karenanya, suatu perusahaan yang berkinerja baik dapat menjadi berita baik bagi investor dan seharusnya mendapat reaksi positif dari pasar (Sandra, 2018).

\section{Dividen}

\section{Pengertian Dividen}

Dividen merupakan pembagian keuntungan kepada pemegang saham yang sebanding dengan jumlah lembar saham yang dimiliki (Baridwan, 2004).

\section{Jenis-jenis Dividen}

Terdapat beberapa jenis dividen, yaitu pertama dividen yang dibayarkan dalam bentuk tunai (cash dividend) atau dalam bentuk tambahan saham (stock dividend). Dividen tersebut akan menambah jumlah saham beredar, namun tidak menambah jumlah dana di dalam modal saham. Kedua, dividen reguler yang dibayarkan dalam bentuk uang tunai yang ditentukan oleh manajemen perusahaan.

Ketiga, dividen khusus (special dividend), yaitu dividen yang dibayarkan sebagai tambahan dari dividen reguler. Keempat, dividen likuidasi, dimana merupakan kelebihan dari laba ditahan atau sisa laba yang tertera dalam nilai buku (Gumanti, 2013). 


\section{Waktu-Waktu Penting dalam Proses Dividen}

Tahap pertama, dividend declaration date merupakan tanggal dimana dewan direksi mengumumkan jumlah dividen tunai yang akan dibayarkan pada periode waktu tertentu. Tanggal tersebut penting untuk dicermati karena pengumuman tersebut yang nantinya akan menaikkan atau menurunkan atau tetap menjaga tingkat dividen yang mengandung informasi tertentu untuk dijadikan dasar penilaian perusahaan oleh investor. Kedua, ex-dividend date, dimana merupakan batas waktu investor dalam membeli saham agar dapat menerima dividen.

Ketiga, holder-of-record date, waktu dimana perusahaan menutup transfer buku saham dan membuat daftar pemegang saham yang berhak meneriman dividen. Tahap terakhir adalah dividen payment date, dimana manajemen melakukan pembayaran kepada pemegang saham, baik melalui cek atau transfer bank. Selain keempat tahap tersebut, terdapat istilah lain dalam pembahasan dividen, yaitu cum dividend. Cum dividendi merupakan kondisi dimana pembeli saham masih berhak meneriman dividen sampai dengan ex-dividend date (Gumanti, 2013).

\section{Capital Gain}

Capital gain merupakan keuntungan investor atas selisis positif dari harga jual dan beli saham. Investor dapat memperoleh capital gain dengan cara membeli saham ketika harga rendah, kemudian menjualnya ketika harga tinggi.

\section{Kurs}

Kurs merupakan nilai tukar mata uang asing terhadap mata uang dalam negeri suatu negara. Kurs yang menguat dapat menjadi penanda bahwa perekonomian suatu negara sedang berkembang dan menarik untuk kegiatan investasi.

\section{Pengembangan Hipotesis}

\section{Pengaruh dividen announcements terhadap trading volume activity}

Dividen merupakan keuntungan yang dibagikan kepada pemegang saham dari perusahaan di akhir periode. Berdasarkan teori signaling, pembagian dividen dianggap sebagai suatu signal bahwa perusahaan memiliki kinerja yang baik. Dimana pasar akan merespon dengan harga yang tinggi ketika terjadi peningkatan dividen dan menurun ketika terjadi pemotongan dividen.

Menurut Subiyanto (2015) pengumuman pembagian dividen tidak signifikan terhadap volume perdagangan saham. Sejalan dengan hal itu Mudalige dan Kalev (2016) menunjukkan bahwa investor institusi menunjukkan volume perdagangan tak normal sebelum dan sesudah dividen diumumkan. Namun, investor individu menunjukkan abnormal trading volume hanya setelah pengumuman dividen. Konsisten dengan hasil yang diharapkan dimana volume perdagangan tak normal secara statistik tidak signifikan di sekitar pengumuman dividen.

Sedangkan menurut Kayana dkk. (2018) terdapat perbedaan hasil, dimana pada tahun 2016 tidak terdapat perbedaanyang signifikan antara trading volume activity sebelum dan sesudah pengumuman dividen secara signifikan, sementara pada tahun 2017 terdapat perbedaan yang signifikan.

Berdasarkan teori dan penelitian terdahulu, maka penulis merumuskan hipotesis sebagai berikut:

H1: Deviden announcements berpengaruh positif signifikan terhadap trading volume activity 


\section{Pengaruh capital gain terhadap trading volume activity}

Capital gain merupakan keuntungan investor dari selisih positif antara harga jual dan beli saham. Investor dapat memperoleh capital gain dengan membeli saham ketika harga rendah dan menjualnya ketika harga tinggi. Keuntungan yang diperoleh nantinya akan berdampak pada peningkatan penjualan saham.

Menurut Subiyanto (2015) capital gain berpengaruh terhadap volume perdagangan saham. Sejalan dengan hasil penelitian tersebut Sudibyo (2016) menunjukkan bahwa capital gain berpengaruh positif dan signifikan terhadap volume perdagangan saham

Berdasarkan uraian dan penelitian terdahulu, maka penulis merumuskan hipotesis sebagai berikut:

H2: Capital gain berpengaruh positif signifikan terhadap trading volume activity

\section{Pengaruh kurs terhadap trading volume activity}

Kurs menunjukkan besaran rupiah yang dibutuhkan untuk memperoleh uang asing (Nazir, 1998). Artinya, apabila kurs tinggi, maka perusahaan yang menggunakan bahan baku impor akan mengeluarkan biaya produksi yang tinggi juga, begitu juga sebaliknya. Selain itu, fluktuasi kurs yang cenderung kurang stabil akan mempengaruhi kepercayaan investor.

Menurut Kumar (2019) trading volume dan nilai tukar memiliki hubungan negatif dan signifikan.

Menurut Prasetioningsih, dkk (2016) nilai tukar rupiah berpengaruh positif dan signifikan terhadap return saham.

Berdasarkan uraian dan penelitian terdahulu, maka penulis merumuskan hipotesis sebagai berikut:

\section{H3: Kurs berpengaruh positif signifikan terhadap trading volume activity}

\section{METODE PENELITIAN}

\section{Jenis Penelitian}

Berdasarkan data penelitian ini berjenis kuantitatif dan berdasarkan cara memperoleh penelitian ini berdata sekunder dengan data panel. Data diperoleh dari website $\mathrm{idx}$, yahoo finance, website resmi perusahaan yang menjadi objek penelitian dan Bank Indonesia.

\section{Populasi dan Sampel}

Populasi dalam penelitian ini, yaitu saham syariah yang terdaftar di JII pada tahun 2015-2018. Sedangkan sampel penelitian ini, yaitu perusahaan yang selalu masuk ke dalam indeks JII dari tahun 2015-2018 serta yang menyediakan data terkait dengan penelitian.

Maka, diperoleh sampel penelitian yaitu, ADRO (Adaro Energy Tbk.), ASII (Astra International Tbk.), INDF (Indofood Sukses Makmur Tbk.), LPFF (Matahari Departement Store Tbk.), PGAS (Perusahaan Gas Negara (Persero) Tbk.), PTBA (Tambang Batubara Bukit Asam (Peersero) Tbk.), SMRA (Summarecoon Agung Tbk.), dan UNTR (Unites Tractors Tbk.). Teknik yang digunakan dalam pengambilan sampel, yakni purposive sampling. Adapun kriteria-kriteria yang harus dipenuhi sebagai berikut:

a. Perusahaan secara berturut-turut masuk ke dalam JII selama tahun 2015-2018.

b. Perusahaan yang melakukan pembagian dividen selama tahun 2015-2018. 
c. Perusahaan yang memberikan informasi terkait capital gain selama 20152018.

\section{Definisi Operasional Variabel Variabel Dependen}

Variabel dependen adalah variabel yang diberi perhatian utama dan merupakan faktor investigasi penelitian (Sekaran, 2006). Trading volume activity (TVA) digunakan untuk mengukur volume perdagagan suatu saham. alasan peneliti memilih TVA yakni, dengan mengetahui nilai TVA maka dapat mengetahui reaksi pasar terhadap informasi-informasi yang dikeluarkan oleh perusahaan.

Rumus menghitung traading volume activity:

Jumlah saham diperdagangkan pada waktu $\mathrm{t}$

TVA $=$

Jumlah saham beredar pada waktu $\mathrm{t}$

\section{Variabel Independen}

Variabel independen adalah variabel yang dapat mempengaruhi variabel terikat, baik berpengaruh positif maupun berpengaruh negatif (Sekaran, 2006).

\section{Dividen Announcements}

Dividen adalah keuntungan yang dibagikan kepada pemegang saham oleh perusahaan pada akhir periode. Alasan peneliti memilih dividen karena dengan adanya pembagian dividen memberikan signal dari perusahaan terhadap investor bahwa perusahaan memiliki kinerja yang baik. Dan dianggap dengan adanya pengumuman dividen akan memberikan informasi yang cukup untuk menentukan pengambilan keputusan investor.

\section{Capital Gain}

Capital gain merupakan keuntungan investor dari selisih positf harga jual beli saham. informasi terkait capital gain dapat diperoleh melalui laporan keuangan tahunan perusahaan.

\section{Kurs}

Kurs merupakan nilai tukar mata uang asing terhadap mata uang dalam negeri suatu negara. Alasan penulis memasukkan variabel kurs bahwasannya tidak menutup kemungkinan suatu perusahaan dalam melakukan kegiatan operasionalnya melakukan impor ataupun ekspor. Baik untuk mendapatkan bahan baku maupun mendistribusikan produknya. Sehingga, kondisi kurs juga akan mempengaruhi besaran biaya yang harus dikeluarkan perusahaan dalam rangka membiayai kegiatan operasionalnya.

Selain itu, fluktuasi kurs yang cenderung kurang stabil akan mengurangi kepercayaan seorang investor. Kurs yang digunakan dalam penelitian ini adalah kurs referensi yang disusun berdasarkan transaksi dolar/rupiah di pasar valuta asing melalui monitoring di Bank Indonesia secara real time. 


\section{Teknik Analisis Data}

\section{Pengujian dividend announcements terhadap TVA}

a. Penentuan periode pengamat

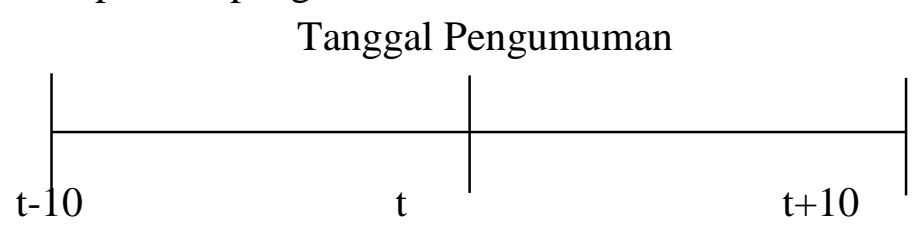

Periode pengamatan yang ditetapkan selama 20 hari, yaitu 10 hari sebelum dan 10 hari setelah pengumuman dividen. Alasan penggunaan periode pengamatan tersebut adalah periode cum dividen akan terjadi kurang lebih 10 hari setelah pengumuman dividen. Sehingga pada periode sebelum dan sesudah pengumuman dividen reaksi pasar dapat terlihat, yakni dengan keputusan investor akan membeli atau menjual saham (Putra dan Arfan, 2013).

b. Menghitung volume perdagangan saham 10 hari sebelum dan 10 hari setelah pengumuman

Jumlah saham diperdagangkan pada waktu $t$

TVAi, $\mathrm{t}=\overline{\text { Jumlah saham beredar pada waktu } \mathrm{t}}$

Keterangan:

TVAi, $\mathrm{t}=$ TVA saham i pada waktu $\mathrm{t}$

$\mathrm{i}=$ nama saham

$\mathrm{t}=$ waktu tertentu

c. Menghitung rata-rata volume perdagangan relatif untuk sampel secara keseluruhan.

rata-rata TVAt $=\frac{\text { TVAi,t }}{n}$

Keterangan:

rata-rata TVAt $=$ rata-rata volume perdagangan relatif pada waktu $\mathrm{t}$

TVAi,t $=$ TVA saham i pada waktu $\mathrm{t}$

$\mathrm{n} \quad$ = jumlah saham

d. Menghitung rata-rata aktivitas volume perdagangan harian saham, yaitu:

rata-rata TVA sebelum pengumuman dividen, dan

rata-rata TVA sesudah pengumuman dividen

e. Uji normalitas data.

Pengujian ini bertujuan untuk mengetahui distribusi data dalam variabel. Metode yang digunakan, yaitu Kolmogorov-Smirnov.

f. Pengujian Hipotesis

Pengujian hipotesis menggunakan pengujian beda rata-rata, yaitu uji t. Jika data berdistribusi normal, maka menggunakan paired sample t test dan jika data tidak berdistribusi normal, maka menggunakan two related sample test dengan software SPSS. 
Pengujian capital gain dan kurs terhadap trading volume activity

Metode analisis data yang digunakan di dalam penelitian ini adalah metode analisis regresi linier berganda yang dibantu dengan software Eviews 9.Model regresi linier berganda yang digunakan adalah sebagai berikut:

$\mathrm{Y}_{\mathrm{it}}=\alpha_{0}+\beta_{1} \mathrm{X}_{\mathrm{it}}+\beta_{2} \mathrm{X}_{\mathrm{it}}+\mathrm{e}$

Dimana:

$\mathrm{Y}_{\mathrm{it}}=$ Trading Volume Activity $i$ tahun ke $t$

$\alpha_{0}=$ Konstata

$\beta_{1,} \beta_{2},=$ Koefisien Regresi

$\mathrm{X}_{\mathrm{it}}=$ Capital Gain

$\mathrm{X}_{\mathrm{it}}=$ Kurs

$\mathrm{e}=$ error

\section{HASIL PENGUJIAN HIPOTESIS}

\section{Pengujian dividend announcements terhadap TVA}

\section{Uji Normalitas Data}

Tabel 1. Uji Normalitas Data 2015

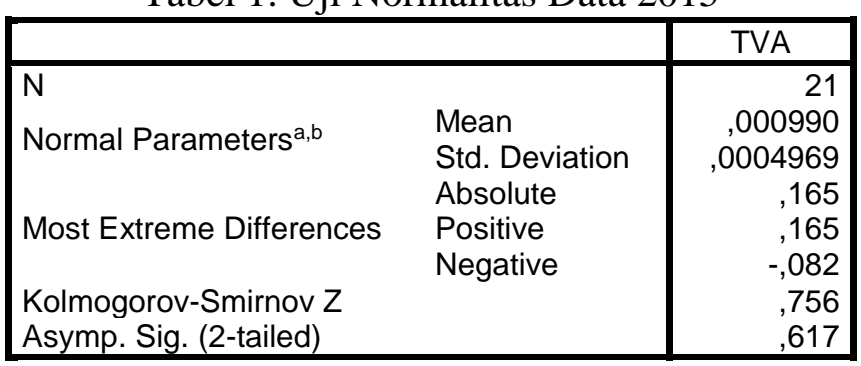

a. Test distribution is Normal.

b. Calculated from data.

(Sumber: data diolah, 2020)

Tabel 2. Uji Normalitas Data 2016

\begin{tabular}{|c|c|c|}
\hline & & TVA \\
\hline $\mathrm{N}$ & & 21 \\
\hline Normal Parameters $\mathrm{a,b}$ & Mean & ,001395 \\
\hline & $\begin{array}{l}\text { Std. Deviation } \\
\text { Absolute }\end{array}$ & , 0012615 \\
\hline Most Extreme Differences & Positive & 194 \\
\hline & Negative &,- 167 \\
\hline Kolmogorov-Smirnov Z & & ,891 \\
\hline Asymp. Sig. (2-tailed) & & ,405 \\
\hline
\end{tabular}

a. Test distribution is Normal.

b. Calculated from data.

(Sumber: data diolah, 2020)

Tabel 3. Uji Normalitas Data 2017

\begin{tabular}{|c|c|c|}
\hline & TVA \\
\hline $\mathrm{N}$ & & 21 \\
\hline Normal Parameters ${ }^{a, b}$ & Mean & ,000724 \\
\hline 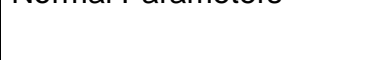 & $\begin{array}{l}\text { Std. Deviation } \\
\text { Absolute }\end{array}$ & $\begin{array}{r}, 0004516 \\
138\end{array}$ \\
\hline Most Extreme Differences & Positive &, 115 \\
\hline & Negative &,- 138 \\
\hline Kolmogorov-Smirnov Z & & ,634 \\
\hline Asymp. Sig. (2-tailed) & & ,816 \\
\hline
\end{tabular}


a. Test distribution is Normal.

b. Calculated from data.

(Sumber: data diolah, 2020)

Tabel 4. Uji Normalitas Data 2018

\begin{tabular}{|ll|r|}
\hline N & & \multicolumn{1}{|c|}{ TVA } \\
Normal Parameters & 21 \\
& Mean &, 001152 \\
& Std. Deviation &, 0009938 \\
Most Extreme Differences & Absolute &, 267 \\
& Positive &, 267 \\
Kolmogorov-Smirnov Z & Negative & -177 \\
Asymp. Sig. (2-tailed) & & 1,223 \\
\hline
\end{tabular}

a. Test distribution is Normal.

b. Calculated from data.

(Sumber: data diolah, 2020)

Berdasarkan pengujian normalitas dari masing-masing periode yakni 2015, 2016, 2017 hingga 2018 diperoleh nilai Asymp.Sig.(2-tailed) 0.617, 0.405, 0.816, dan 0.100 yang mana $>0.05$ yang berarti data berdistribusi normal. Oleh karena data berdistribusi normal, maka pengujian selanjutnya menggunakan paired sample t test.

\section{Pengujian Hipotesis}

Tabel 5. Uji Paired Sample t Tes 2015

\begin{tabular}{|l|l|l|}
\hline TVA 2015 & Mean & Sig. (2-tailed) \\
\hline $\begin{array}{l}\text { TVA sebelum pengumuman dividen- } \\
\text { TVA sesudah pengumuman dividen }\end{array}$ & 0.0001000 & 0.707 \\
\hline
\end{tabular}

(Sumber: data diolah, 2020)

Tabel 6. Uji Paired Sample t Tes 2016

\begin{tabular}{|l|l|l|}
\hline TVA 2016 & Mean & Sig. (2-tailed) \\
\hline $\begin{array}{l}\text { TVA sebelum pengumuman dividen- } \\
\text { TVA sesudah pengumuman dividen }\end{array}$ & 0.0002800 & 0.584 \\
\hline
\end{tabular}

(Sumber: data diolah, 2020)

Tabel 7. Uji Paired Sample t Tes 2017

\begin{tabular}{|l|l|l|}
\hline TVA 2017 & Mean & Sig. (2-tailed) \\
\hline $\begin{array}{l}\text { TVA sebelum pengumuman dividen- } \\
\text { TVA sesudah pengumuman dividen }\end{array}$ & 0.0000700 & 0.774 \\
\hline
\end{tabular}

(Sumber: data diolah, 2020)

Tabel 8. Uji Paired Sample t Tes 2018

\begin{tabular}{|l|l|l|}
\hline TVA 2018 & Mean & Sig. (2-tailed) \\
\hline $\begin{array}{l}\text { TVA sebelum pengumuman dividen- } \\
\text { TVA sesudah pengumuman dividen }\end{array}$ & 0.0009000 & 0.049 \\
\hline
\end{tabular}

(Sumber: data diolah, 2020)

Berdasarkan hasil uji paired sample $t$ test diperoleh sig.(2-tailed) untuk masing-masing tahun 2015, 2016, 2017 adalah 0.707, 0.584, 0.774 yang mana > 0.05, artinya tidak terdapat perbedaan yang signifikan antara sebelum pengumuman dividen dan sesudah pengumuman dividen. Sedangkan hasil 
pengamatan di tahun 2018 yaitu $0.049<0.05$, artinya terdapat perbedaan yang signifikan antara sebelum pengumuman dividen dan sesudah pengumuman dividen.

\section{Pengujian capital gain dan kurs terhadap trading volume activity}

\section{Uji Normalitas}

Tabel 9. Uji Normalitas

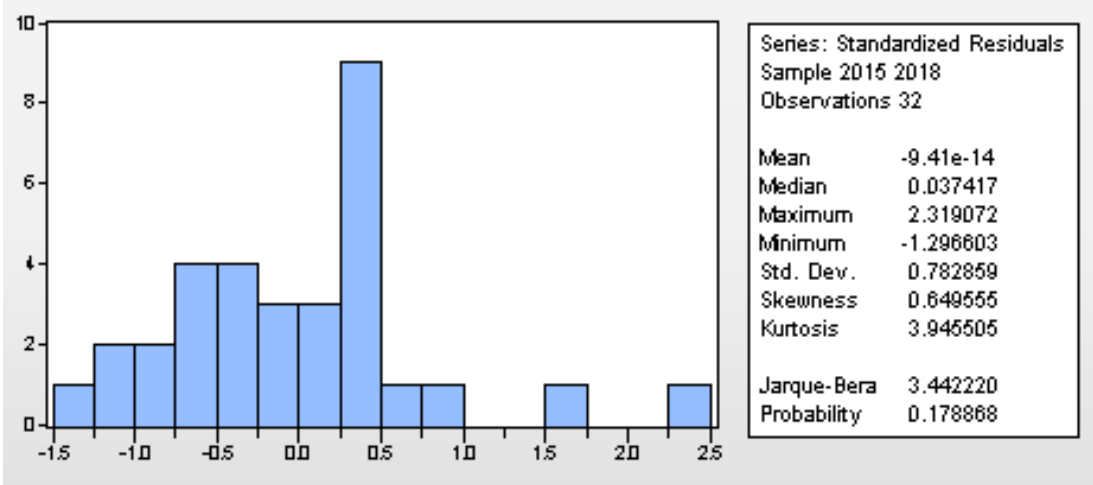

(Sumber: data diolah, 2020)

Berdasarkan tabel di atas diketahui bahwa nilai probabilitas dari Jarque-Bera adalah $0.178868>0.05$, sehingga residual berdistribusi normal.

\section{Uji Analisis Regresi Linier Berganda}

Tabel 10. Uji Regresi Linier Berganda

\begin{tabular}{crrrr}
\hline \hline Variable & Coefficient & Std. Error & t-Statistic & Prob. \\
\hline \hline $\mathrm{C}$ & -1.855154 & 0.663292 & -2.796890 & 0.0091 \\
$\mathrm{X} 2$ & -0.000494 & 0.000316 & -1.561378 & 0.1293 \\
$\times 3$ & 0.195215 & 0.069676 & 2.801759 & 0.0090 \\
\hline \hline
\end{tabular}

(Sumber: data diolah, 2020)

Berdasarkan tabel di atas dapat dibentuk persamaan regresi berganda sebagai berikut:

$\mathrm{Y}=-1,855154-0.000494 \mathrm{X}_{2}+0.195215 \mathrm{X}_{3}+\mathrm{e}$

Keterangan:

$\mathrm{Y}=$ Trading Volume Activity (TVA)

$\mathrm{X}_{2}=$ Capital Gain

$\mathrm{X}_{3}=$ Kurs

Berdasarkan persamaan regresi di atas, nilai koefisien dapat diinterpretasikan sebagai berikut:

Nilai konstanta dari persamaan tersebut adalah -1,855154. Hal ini dapat diartikan jika nilai dari variabel capital gain dan kurs adalah 0, maka nilai TVA adalah $-1,855154$.

Variabel capital gain tidak signifikan diangka keyakinan 95\% karena nilai probabilitasnya $0,1293>0,05$. Koefisien regresi capital gain sebesar -0.000494 yang menggambarkan bahwa setiap kenaikan satu-satuan, maka capital gain akan menurunkan TVA sebesar 0.000494 .

Variabel kurs signifikan diangka keyakinan 95\% karena nilai probabilitasnya $0,0090<0,05$. Koefisien regresi kurs sebesar 0,195215 yang menggambarkan 
bahwa setiap kenaikan satu-satuan, maka kurs akan menaikkan TVA sebesar 0,195215 .

\section{Koefisien Determinasi}

Nilai koefisien determinasi ini menunjukkan kemampuan garis regresi menerangkan variasi variabel dependen atau sejauh mana variabel dependen dapat dijelaskan oleh variabel independen.

Tabel 11. Uji Koefisien Determinasi

\begin{tabular}{|c|c|}
\hline Indikator & Nilai \\
\hline Adjusted $R$-Squared & 0.219512 \\
\hline
\end{tabular}

(Sumber: data diolah, 2020)

Berdasarkan hasil regresi, diperoleh nilai Adjusted R-Square 0.219512 yang berarti bahwa variabel independen capital gain dan kurs secara bersama-sama berpengaruh terhadap variabel dependen TVA sebesar 21,95 \%, sedangkan sisanya 78,05 dijelaskan oleh variabel lain di luar model.

\section{Uji F}

Uji $F$ adalah uji yang digunakan untuk mengetahui pengaruh variabel independen terhadap variabel dependen secara bersama-sama.

Tabel 12. Uji F

\begin{tabular}{|c|c|}
\hline Indikator & Nilai \\
\hline Prob $($ F-Statistic) & 0.010455 \\
\hline
\end{tabular}

(Sumber: data diolah, 2020)

Berdasarkan Tabel 12 dengan alfa 5\% diketahui bahwa probabilitas dari $\mathrm{F}$ statistik adalah 0,010455. Artinya bahwa variabel capital gain dan kurs secara bersama-sama berpengaruh signifikan terhadap variabel TVA.

\section{Pengujian Koefisien Regresi secara Parsial (Uji t)}

Uji t digunakan untuk mengetahui pengaruh variabel independen terhadap variabel dependen secara parsial dengan asumsi bahwa variabel lain tetap.

a. Pengaruh capital gain terhadap tradinng volume activity

Berdasarkan tabel 10, diketahui bahwa nilai probabilitas variabel capital gain sebesar $0,1293>0,05$, sehingga $\mathrm{H}_{0}$ diterima. Artinya bahwa variabel capital gain tidak berpengaruh terhadap trading volume activity.

b. Pengaruh kurs terhadap trading volume activity

Berdasarkan tabel 10, diketahui bahwa nilai probabilitas variabel kurs sebesar $0,0090<0,05$, sehingga $\mathrm{H}_{0}$ ditolak. Artinya bahwa variabel kurs berpengaruh positif dan signifikan terhadap trading volume activity.

\section{Pembahasan}

a. Pengaruh dividen announcements terhadap trading volume activity.

Berdasarkan hasil pengujian diperoleh perbedaan hasil antara pengaruh dividen announcements terhadap TVA dimana pada tahun 2015, 2016 dan 2017 tidak terdapat perbedaan yang signifikan antara sebelum pengumuman dan sesudah pengumuman dividen. Sedangkan hasil pengujian di tahun 2018 ditemukan adanya perbedaan yang signifikan antara sebelum dan sesudah pengumuman dividen.

Hasil tersebut sejalan dengan Kayana, dkk. (2018) dimana dalam penelitiannya juga terdapat perbedaan hasil dimana pada tahun 2016 tidak 
terdapat perbedaan signifikan, sedangkan tahun 2017 terdapat perbedaan yang signifikan antara sebelum dan sesudah pengumuman dividen.

Hasil yang menunjukkan bahwa tidak terdapat perbedaan yang signifikan antara sebelum pengumuman dividen dan setelah pengumuman dividen didukung oleh teori yang menyatakan bahwa pembagian dividen akan mengurangi persediaan kas perusahaan. Sehingga akan meningkatkan leverage, dimana hal tersebut berdampak pada posisi modal yang semakin menurun dan para calon investor akan berpikiran negatif terhadap perusahaan (Kayana, 2018).

Hasil yang menunjukkan bahwa terdapat perbedaan yang signifikan antara sebelum pengumuman dividen dan sesudah pengumuman dividen sesuai dengan teori signaling. Dimana perusahaan yang ingin menyampaikan informasi terkait kualitas perusahaan dengan cara yang tidak dapat ditiru oleh perusahaan lainnya, yakni dengan membayarkan dividen dalam jumlah yang relatif besar. Yang mana pasar akan merespon dengan harga yang meningkat dengan adanya peningkatan dividen dan menurun dalam jumlah besar ketika terjadi pemotongan dividen (Arifin, 2007).

\section{b. Pengaruh capital gain terhadap trading volume activity}

Berdasarkan hasil pengujian diketahui bahwa capital gain tidak berpengaruh terhadap trading volume activity. Hasil tersebut bertolak belakang dengan penelitian Subiyanto (2015) dan Sudibyo (2016) yang menyatakan bahwa capital gain berpengaruh terhadap volume perdagangan saham.

Dalam kondisi tertentu capital gain susah untuk diharapkan seiring pergerakan pasar yang tipis. Pada tahun 2015 bursa saham mengalami penurunan karena laju ekonomi yang tidak bisa memenuhi ekspektasi hingga minus 12,13. Beberapa tahun kemudian pada 2018 kinerja IHSG menjadi yang terburuk dalam kurun waktu 3 tahun terakhir dengan minus 2,54\%. Sedangkan tahun 2017 dan 2016 masih memberikan return 19,99\% dan 15,32\% (www.cnbcindonesia.com). Berdasarkan fenomena tersebut dapat diketahui bahwa kondisi pasar dalam kurun waktu tersebut tidak dalam kondisi yang cukup baik.

\section{c. Pengaruh kurs terhadap trading volume activity}

Berdasarkan hasil pengujian diketahui bahwa kurs berpengaruh positif signifikan terhadap trading volume activity. Hasil tersebut sejalan dengan hasil penelitian Subiyanto (2015) dan Sudibyo (2016), namun tidak sejalan dengan Kumar (2019) yang menyatakan bahwa hubungan antara trading volume dan nilai tukar signifikan dan negatif. Apabila kurs rupiah menguat, maka investor akan tertarik untuk berinvestasi. Hal itu karena adanya potensi keuntungan kurs yang bisa mereka peroleh.

\section{KESIMPULAN, KETERBATASAN DAN SARAN Kesimpulan}

a. Berdasarkan hasil pengujian hipotesis antara dividen announcemen terhadap trading volume activity bahwa pada tahun 2015, 2016 dan 2017 tidak terdapat perbedaan yang signifikan antara sebelum dan sesudah pengumuman dividen. Sedangkan pada tahun 2018 menunjukkan adanya perbedaan yang signifikan antara sebelum dan sesudah pengumuman dividen. 
b. Berdasarkan hasil pengujian hipotesis, variabel capital gain tidak memiliki pengaruh yang signifikan terhadap variabel trading volume activity.

c. Berdasarkan hasil pengujian hipotesis, variabel kurs memiliki pengaruh positif dan signifikan terhadap variabel trading volume activity.

\section{Keterbatasan dan Saran}

a. Untuk investor diharapkan dapat mencermati informasi-informasi yang berkaitan dengan keputusan investasi, baik informasi yang diberikan oleh perusahaan maupun informasi dari luar perusahaan.

b. Untuk peneliti selanjutnya dapat menambahkan variabel-variabel lainnya yang dapat mempengaruhi keputusan investor dalam melakukan investasi, seperti variabel makro ekonomi. Pada penelitian ini menggunakan objek saham syariah yang terdaftar di JII, penelitian selanjutnya dapat menggunakan objek lain atau menambahkan periode penelitian agar memperkuat hasil penelitian.

\section{DAFTAR PUSTAKA} 2008. Teori Portofolio dan Analisis Investasi. Yogkakarta: BPFE.

Arifin, Zaenal. 2007. Teori Keuangan \& Pasar Modal. Yogyakarta: EKONISIA.

Baridwan, Zaki. 2004. Intermediate Accounting. Edisi 8. Yogyakarta: BPFE.

Fama, Eugene F. dan Harvey Babiak. 1968. Dividen Policy: An Empirical Analysis. Journal of the American Statistical Association, 63 (324), 1132-116

Gumanti, Tatang Ary. 2013. Kebijakan Dividen Teori, Empiris dan Implikasi. Yogyakarta: UPP STIM YKPN.

Jogiyanto. 2000. Teori Portofolio dan Analisis Investasi, Edisi Kedua. Yogyakarta: BPFE.

Kim, Kyung Soo, et.al. 2017. Differential Informativeness of Analyst Reports by Investor Types Evidence from the Korean Stock Market. Managerial Finance, 43 (5) pp. 567- 594

Kristiyanto, Setya, Sri Hermuningsih. 2018. Pengaruh Peristiwa Bom Thamrin terhadap Return Saham dan Trading Volume Activity pada Perusahaan LQ45 yang terdaftar di Bursa Efek Indonesia. Jurnal Manajemen Dirgantara, 2 (1), 55-67

Kumar, Satish. 2019. The Relationship between Trading Volume and Exchange Rate Volatility: Linear or Nonlinear. International Journal of Managerial, 15 (1), 19-38

Lintner, John. 1956. Distribution of Incomes of Corporation Among Dividens, Retained Earnings, and Taxes. American Economic Review, 46 (2), 97113 
Kompartemen: Jurnal Ilmiah Akuntansi/September 2020, XIX (2), 1-15

Mudalige, Priyantha dan Petko S. Kalev. 2016. Individual and Institutional Trading Volume Around Firm-Specifik Announcements. International Journal of Managerial Finance, 12 (4), 422-444

Munjin, Ahmad. 2009. Jangan Berharap dari Dividen Saham. Diakses tanggal 09 Februari 2020 dari https://inilah.com/news/88288/jangan-berharap-daridividen-saham

Prasetioningsing, Devi, dkk. 2018. Pengaruh Nilai Tukar Rupiah terhadap Return Saham yang Terdaftar di Bursa Efek Indonesia (Studi Kasus Perusahaan LQ 45 Periode Januari 2012-Desember 2015. Journal of Management, 4 (4),

Putra, Iman Rafiyal dan Muhammad Arfan. 2013. Reaksi Pasar terhadap Pengumuman Dividen Kas (Studi pada Perusahaan yang Terdaftar di Bursa Efek Indonesia). Jurnal Telaah \& Riset Akuntansi, 6 (1), 40-53

Rahmi, Ika Prida dan Sri Wahyuni Jamal. (2019). Analisis BI Rate dan Kurs Rupiah terhadap Volume Perdagangan Saham di Bursa Efek Indonesia Periode Tahun 2016-2018. Borneo Student Research, 1 (1), 585-592

Sekaran, Uma. 2006. Research Methods for Business. Jakarta: Salemba Empat.

Subiyanto, Dodik. 2015. Analisis Pengaruh Capital Gain dan Pembagian Dividen terhadap Volume Perdagangan Saham. Skripsi. tidak dipublikasikan. Universitas Muhammadiyah Surakarta 